\title{
Have the Special Economic Zones Succeeded in Attracting FDI?-Analysis for India
}

\author{
Tamali Chakraborty ${ }^{*}$, Haripriya Gundimeda ${ }^{2}$, Vinish Kathuria ${ }^{3}$ \\ ${ }^{1}$ Department of Humanities and Social Sciences (H\&SS) of Indian Institute of Technology (IIT) Bombay, Mumbai, India \\ ${ }^{2}$ Department of H\&SS, IIT Bombay, Mumbai, India \\ ${ }^{3}$ School of Management of IIT Bombay, Mumbai, India \\ Email: *tamali.chakraborty@gmail.com, haripriya@hss.iitb.ac.in, vinishk@som.iitb.ac.in
}

How to cite this paper: Chakraborty, T., Gundimeda, H. and Kathuria, V. (2017) Have the Special Economic Zones Succeeded in Attracting FDI?-Analysis for India. Theoretical Economics Letters, 7, 623642. https://doi.org/10.4236/tel.2017.73047

Received: March 21, 2017

Accepted: April 24, 2017

Published: April 27, 2017

Copyright $\odot 2017$ by authors and Scientific Research Publishing Inc. This work is licensed under the Creative Commons Attribution International License (CC BY 4.0).

http://creativecommons.org/licenses/by/4.0/ (c) (i) Open Access

\begin{abstract}
The introduction of Special Economic Zones (SEZs) in India has injected hope for augmented economic growth in recent future. The motive behind establishment of SEZs was mainly to fuel rapid economic growth, provide world class infrastructure and employment, promote exports, increase foreign exchange reserves and attract more Foreign Direct Investment (FDI). The main objective of the paper is to investigate whether the enactment of SEZ policies had any impact on inflow of FDI among Indian states. This is tested using panel data techniques on 16 groups of states over 14 years period from 2001 to 2014. The results indicate that enactment of SEZ policy (as well as operational SEZs) in a state has induced more FDI inflow. Based on the results, it can be concluded that the states, which want to benefit from FDI inflow, they need to enact the policies sooner.
\end{abstract}

\section{Keywords}

Special Economic Zones, Special Economic Zone Policy, Foreign Direct Investment, Panel Data Model, India

\section{Introduction}

Recognising the importance of export promotion in triggering the economic growth, the Government of India established the first Export Processing Zone (EPZ) at Kandla in 1965 [1]. Thereafter in next three decades, several EPZs were established namely, Kandla EPZ, Santacruz EPZ, Noida EPZ, Falta EPZ, Cochin EPZ, Chennai EPZ, Visakhapatnam EPZ and Surat EPZ. The EPZs, however, were not successful in ensuring the needed development due to rigid government laws, high transportation costs, long delays in obtaining permits ([2] [3]) and locational disadvantages ([2] [4] [5] [6]). To overcome the shortcomings of 
EPZs and having acknowledged the phenomenal success of Special Economic Zones (SEZs) in China, Indian government promoted the SEZs ${ }^{1}$ in 2000 with a view to promote industrial activity, create infrastructure, attract Foreign Direct Investment (FDI), enhance foreign exchange reserves and promote exports ([7] [8]).

The shift from EPZs to SEZs happened in two phases-conversion of existing EPZs into SEZs during 2000-2003 and fresh approvals of new SEZs after the year 2003. To realise the objectives, the entities were accorded special privileges so as to specially attract investment into the SEZs including the foreign investment. The key privileges included-1) duty free import/domestic procurement of goods for development, operation and maintenance of SEZ units; 2) single window clearance from Central and State Approval; 3) 100\% Income Tax exemption on export income for SEZ units under Section 10AA of the Income Tax (IT) Act for first 5 years, $50 \%$ for next 5 years thereafter and $50 \%$ of the ploughed back export profit for next 5 years; 4) exemption from minimum alternate tax under section $115 \mathrm{JB}$ of the IT Act; 5) external commercial borrowing by SEZ units upto US $\$ 500$ million in a year without any maturity restriction through recognised banking channels; and 6) exemption from Central Sales Tax, Service Tax, States sales tax, dividend distribution tax and other levies of the respective State Governments [7].

At present (as on $2^{\text {nd }}$ September 2016), 204 SEZs are operating in India and 18 of these were notified prior to the enactment of SEZ Act (2005). Though SEZs were intended to act as a catalyst for regional development, they are concentrated only in few states (Figure 1). Five states, namely, Andhra Pradesh (AP) (including Telangana), Tamil Nadu (TN), Karnataka, Maharashtra, and Gujarat, have nearly three-fourths (74\%) of the operational SEZs, whereas states like Bihar (including Jharkhand), Goa, Delhi and North-eastern States do not have even a single SEZ. Sector-wise, the maximum approvals have been given in the sectors IT/ITes/Electronics industries (comprising 63\% of total approvals). Table A1 in Appendix gives sector-wise SEZs. The liberal SEZ policies adopted by the states also induce the investors to invest in the SEZs. Few states like Bihar, North eastern states do not have SEZ Act or SEZ Policy while other states like AP, Maharashtra, TN, Punjab, Haryana, Gujarat, Madhya Pradesh (MP) and West Bengal (WB) have SEZ Act or SEZ Policy. These latter group of States have exempted units from all state and local taxes for transactions within the SEZ, have exempted stamp duty and registration fees, thus are able to attract more FDI. These states also have flexible labour policies, and environment related permits are granted through dedicated single window mechanism. Permissions are also given quickly for generation, transmission and distribution of electricity, water extraction, treatment, transport and distribution. Land acquisition is expedited to set up SEZs for public purpose under Land Acquisition Act of $1894^{2}$.

${ }^{1}$ According to the Ministry of External Affairs, Government of India, "Special Economic Zones (SEZ) are specifically delineated duty free enclaves and shall be deemed to be foreign territory for the purpose of trade operations and duties and tariffs" Source:

http://indiainbusiness.nic.in/newdesign/index.php?param=industryservices_landing/369/2 accessed in August 2016.

${ }^{2}$ For details, refer SEZ Acts of WB, Maharashtra, Punjab, Haryana, AP, Gujarat, TN, MP etc., which shows similarities in provisions. 


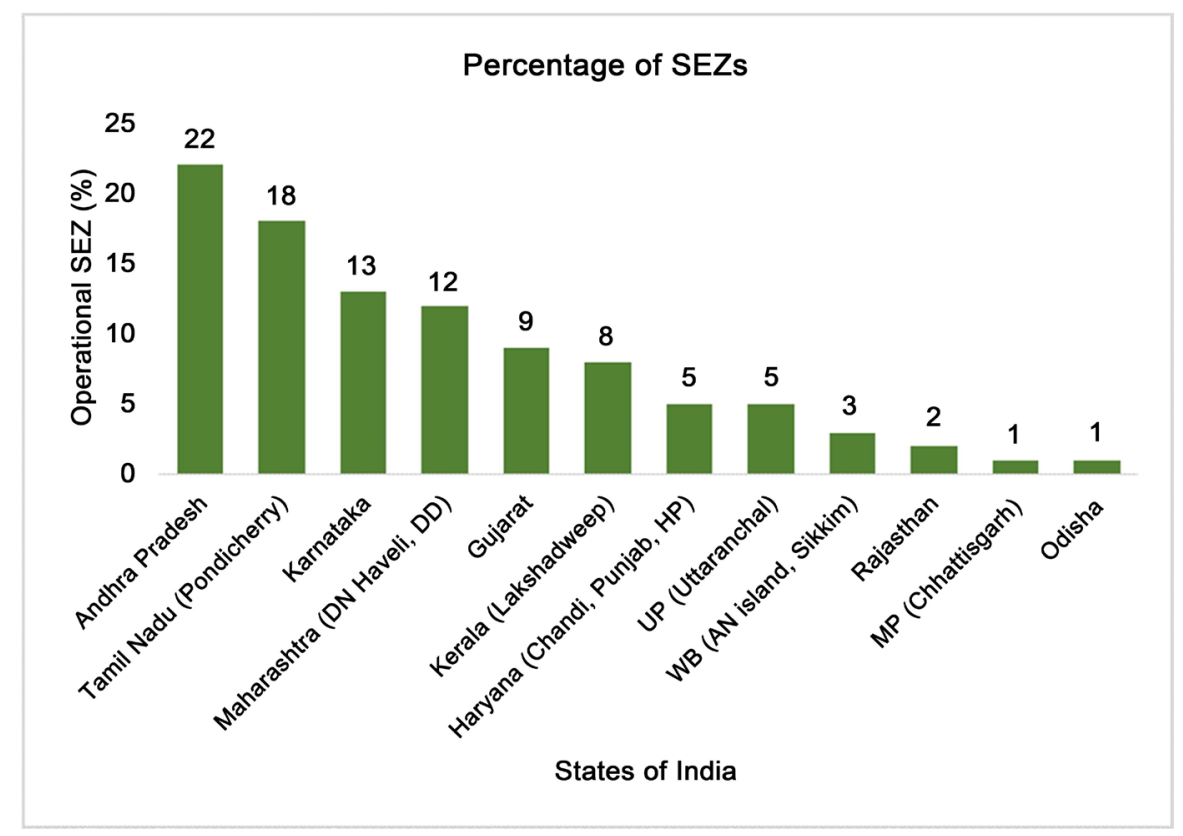

Source: Computed values on the basis of data given in www.sezindia.in accessed in August 2016. Notes. DNH $=$ Dadra and Nagar Haveli; DD = Daman and Diu; TN = Tamil Nadu; WB= West Bengal; AN Islands = Andaman and Nicobar Islands; Chandi = Chandigarh; HP = Himachal Pradesh; MP = Madhya Pradesh; UP = Uttar Pradesh. Also, Delhi, Goa, Bihar (including Jharkhand) and North Eastern States do not have any SEZ.

Figure 1. State-wise Share of SEZs (in percentage).

One of the aims of setting up the SEZs is to attract FDI, given its significant role in economic development [9] and it being an important source of non-debt financial resources [10]. In fact, FDI policies for SEZs are generally more liberal than that of for the country. For example, FDI as permitted in SEZs include 100 per cent FDI through automatic route for all manufacturing activities except for few strategic and security related goods (such as defense equipments, atomic substance etc.), 100 per cent FDI for developing the townships, and facility to set up manufacturing units in SEZs without approval from the Reserve Bank of India $(\mathrm{RBI})^{3}$. Given the key emphasis on attracting units catering for export purpose, it is pertinent to check whether establishment of SEZs have resulted in increased FDI to the state.

Elsewhere, Wang [11] for China has found that SEZs are instrumental to boost FDI, foreign exchange reserves and exports in the country. Another study for China is by Tuan and $\mathrm{Ng}$ [12], which argues that FDI inflow deepens the agglomeration. The study finds that 19 coastal cities, which also included four SEZs (Shenzhen, Zhuhai, Shantou and Ximen) of China, which were opened for FDI earlier attracted almost 11 times higher FDI inflows than other group of 218 cities by 1998. It is also seen in this study that agglomeration is an important factor in attracting FDI and this results in unbalanced regional development [12]. Fujita and $\mathrm{Hu}[13]$ based on their analysis have also concluded the important role of FDI in the biased regional development in China [13]. Cheng and ${ }^{3}$ Kindly refer http://www.oifc.in/special-economic-zone-sez for details about other policies pertaining to FDI in SEZs. 
Kwan [14] find that SEZs located in coastal areas and located nearer to cities are successful in attracting FDI vis-à-vis other SEZs [14]. Thus there is sufficient evidence in literature to suggest that the agglomeration effect of SEZs will bring more FDI to the regions which have these SEZs.

Under this backdrop, the objective of the present study is to examine whether SEZs have helped in attracting FDI in Indian States or not. Such an investigation of the role of SEZs on FDI inflow (having implication for regional growth) context is particularly meaningful in the case of a huge, developing country like India where regional diversity in growth and differential economic performances of states are evident. This is tested using panel data of 16 major Indian states over 14 years period from 2001 to 2014. The results indicate that formulating of SEZ policy in the state has resulted in increased FDI inflow when other factors influencing FDI is accounted for.

The remaining paper is structured as follows. Section 2 reviews the literature looking into the determinants of FDI flows into particular state with specific reference to SEZs. Section 3 discusses the methodology used. The section also gives the data used for the study. Section 4 gives the descriptive statistics of different variables used. This is followed by reporting and discussion of results in Section 5. The paper concludes in Section 6 with policy implications of the study.

\section{Do SEZs Attract FDI?-Review of Literature}

FDI plays a major role in promoting development through transfer of financial resources, transferring technology, promoting innovation and improved management ([15] [16] [17] [18] [19]). While some of the countries (through their specific policies) like India, China and Brazil could attract FDI, other developing countries could hardly attract FDI [20]. India has been among the top ten recipient of FDI along with China in the last 20 years and the quantum of FDI has increased comparatively faster in the post-reform period ([18] [21]). It is important to see what is driving this increased flow of FDI in India.

Researchers have noted that FDI inflow is concentrated in few states of India only (see for example, [22] for the period 1991 to 2002, and [20] for the period 2008-09 to 2011-12). The top six states namely Maharashtra, Delhi, Karnataka, Gujarat, TN and AP have accounted for 70\% of total FDI inflow during 2008-09 to 2011-12, whereas Maharashtra and Delhi together had more than 50\% of FDI inflows [20]. From these two studies, it can be inferred that the top states of India which have received more FDI inflow have remained the same in these two periods excluding Gujarat which was not among top FDI attracting states of India during 1991 to 2002.

The disparities in a host of structural and institutional factors across states has been largely responsible for skewed inflow of FDI [23]. These factors include bigger market size, infrastructural facilities, growing consumer base due to urbanisation and ease for exports resulting in more FDI to a particular state. A similar disparity was noted by an earlier study by Siddharthan [24] for both India and China based on a panel data of 30 provinces over the period 2000 to 
2003. The study finds that FDI inflows, instead of bringing convergence have brought divergence among Indian states as well as Chinese provinces. Most of the domestic and foreign investments were happening in NCR Delhi and in coastal states. The same phenomenon has been noted in China as well. In China, provinces of Eastern zone, which had higher per capita income, had attracted FDI, whereas, the provinces belonging to Western zone have not been able to attract much FDI and are also poorer compared to Eastern zone. In India, the states which received higher FDI also had higher industrial output, higher percapita income (PCI) and have better socio-economic indicators [24]. In China, the provinces with higher FDI enjoyed high PCI with high socio-economic indicator but the reverse is not true. For example, Shanghai in China has the highest per capita FDI inflows and also highest $\mathrm{PCI}^{4}$, while Kerala in India tops in the socio-economic index, human development index, tele-density and life expectancy, it does not attract much FDI and has low industrialisation. Odisha in India has high FDI inflows but has low socio-economic index, human development index, life expectancy, tele-density and low industrialisation. It is likely that proactive reforms undertaken by some of the states could be the reason for this divergence in FDI inflows [25].

Could SEZs attract additional FDI since their establishment? Due to the benefits generated by industrial clusters in attracting FDI and corresponding domestic investment, many developing countries have established these zones [26]. Evidence shows that though EPZs were successful in attracting FDI, especially the export oriented FDI [26], however, other factors, such as labour market inflexibilities may have acted in the negative direction and thus could not perform well in attracting FDI. However, the export-oriented FDI is more affected by labour market rigidities and labour cost than domestic market-seeking FDI [22].

Wang [11] using panel data for 321 prefecture-level municipalities showed that in China SEZs have increased foreign owned capital during 1978 to 2007. Along with SEZs, there were host of other variables like private property rights protection, tax breaks, land use policies which were responsible for increase in FDI [11]. Makabenta [27] has found that the combined effect of variables like regional PCI, number of SEZs in the region, paved highways and existence of ports strongly influenced location of FDI. The study has emphasised that FDI is more attracted towards highly urbanised regions and access to infrastructure, which lower transport costs [27].

Thus, establishment of SEZs is one of the major factors behind attracting FDI. However, the role of other factors cannot be ignored. Which are the other significant factors in attracting FDI? Since the beginning of year 2000, several researchers have examined the determinants of FDI but not with special reference to SEZs. A very positive and significant factor in attracting FDI in SAARC countries (except Maldives, Nepal and Pakistan) is the size of the economy, measured by gross domestic product (GDP) [28]. Same a positive causal relationship between FDI and GDP has also been noted in Slovakia and Cambodia [29].

${ }^{4}$ Per capita income of Shanghai is almost 13 times higher than the per capita income of Guizhou [24]. 
Studies have also noted the significant role played by infrastructure in attracting the FDI ([20] [23] [25] [30] [31] [32]). This might be probably why most of the SEZs in India are concentrated in cities or nearby areas where facilities of road, seaport and airport are available. To attract FDI inflows, countries have facilitated land, power, tax holiday and rebate on undistributed profits, etc. Based on relative infrastructure availability index constructed for 66 countries for 3 different years, Kumar [30] indicated that some countries, such as South Korea, Thailand, Singapore, Costa Rica and Chile have attracted more FDI having good infrastructure compared to others which have poor infrastructure. Banga [31] has shown that in addition to transport and communication infrastructure, labour costs, labour productivity and educational attainment were positive and significant while higher tariffs were shown to be counterproductive in attracting FDI. A recent study by Kathuria [33], though not looking specifically FDI investment, has also corroborated that industries usually agglomerate where infrastructure and market exist.

However, the interstate variation in FDI inflows does not seem to be influenced by infrastructure as shown in a study by Chatterjee [32]. A panel data analysis based on 16 states over the period from 2001-02 to 2005-06 showed that the social, physical and educational infrastructure does not have any significant influence on FDI inflows of Indian states and as FDI in India is mainly market seeking, FDI inflows seem to depend only on profitability and risk factor. Mukherjee [20] while examining the determinants of regional distribution of FDI inflows of India finds that per-capita manufacturing value added has a positive and significant role, wages and tax revenue have a negative and significant impact on FDI, literacy rate does not have any impact on FDI inflow. The study finds that one period lagged value of FDI stock has more impact on FDI inflows and this shows the agglomeration effect. The presence of agglomeration effect indicates that the rich states receive more and more FDI and other states have difficulty in getting new investments [20].

A State with good fiscal prudence or decentralization seems to be another significant factor in attracting FDI. Based on the panel data analysis, Canfei [9] found that a province with more authority in economic matters and strict fiscal budget constraint attracts more FDI inflows. However, more legal spending in a province brings lesser FDI inflow. The economic and political reforms of transitional economies bring FDI inflows [9].

The factors determining the FDI flows can also vary across countries. Sinha, Kent and Shomali [34], examined the FDI flow for India during 1992-2005 and from China during 1978-2005 and found that the factors were very different. The factors attracting FDI in China are infrastructure, policy initiatives for economic freedom, opening up the economy and flexible labour laws. However, the factors attracting FDI in India are the size of Indian economy, exchange rate volatility, extent of corruption, political stability and growth rate. While India was following the policy of import substitution, China has export import oriented growth policy. China grew very fast whereas India was trailing behind. China got 
$\$ 60$ billion dollars in 2005 whereas India did not even get $\$ 6$ billion [34]. It is probably due to the restriction on larger FDI inflows to India, non-transparent sectoral policies of FDI, high tariff rates, lack of good infrastructural facility, lack of decision making authority with the state Governments, limited scale of EPZs, no liberalisation in exit barriers, stringent labour laws, financial sector reforms and high corporate tax rates [25].

Based on above literature review, we can see that there exist several studies which have attempted to find the factors attracting FDI. However, only a handful of studies exist looking into the role of SEZs in attracting FDI. Incidentally, most of these studies are for China. The present study plugs this important gap in the literature by investigating the role of SEZs in attracting FDI in the Indian context.

\section{Methodology and Data}

In this section we describe the methodology looking into the role of SEZs in influencing FDI inflow after accounting for other factors having a significant role. Based on the discussion in the previous section and similar to [35], the factors influencing the decision to choose a particular location in India can be grouped into: 1) market-related factors; 2) labour-related factors; 3) infrastructure; and 4) government policy. Market factors as measured by Gross Sate Domestic Product (GSDP), population, and population density of the state can play an important role in attracting investment. Labour related factors could be the availability, wage rate, and quality of the workforce. Infrastructure variables include transportation network, telephone density, nearness to Ports, airports, length of the highways etc. Lastly, government policies like creation of SEZs, special incentives like giving tax concessions etc. also play a very significant role in attracting FDI.

Thus, in the model we considered the above groups of variables as potential determinants of FDI. The model looking into FDI inflow in a particular state is specified as follows:

$\mathrm{FDI}=\mathrm{f}($ SEZ policy, Market factors, infrastructure, labour measure $)$

\subsection{Model}

We estimated the equation of the form

$$
Y_{i t}=\alpha_{\mathrm{i}}+\beta x_{i t}+\varepsilon_{i t}
$$

where $i$ represent the state and $t$ represents the time for the dependent variable (i.e., FDI inflow), $y$ and the explanatory variables (x); $\alpha$ is the parameter specific to each state and does not vary over time. As explained in the earlier section, the following variables in linear form are considered

$$
\begin{aligned}
\text { LFDI }_{i, t}= & \alpha_{\mathrm{i}}+\beta_{1} \text { LPGSDP }_{\mathrm{i}, \mathrm{t}}+\beta_{2} \text { PELEC }_{i, t}+\beta_{3} \text { HDENSITY }_{i, t} \\
& +\beta_{4} \text { URBANDENSITY }_{i, t}+\beta_{5} \text { NEARPORT }_{i}+\beta_{6} \text { SEZpolicy }_{i, t}+\varepsilon_{i \mathrm{it}}
\end{aligned}
$$

where, $\beta_{1}$ to $\beta_{6}$ are the parameters to be estimated. Our key variable is SEZpolicy 
which is captured as a dummy which takes the value one from the year when a state implements SEZ policy and zero before that. If coefficient of $\beta_{6}$ is positive, this would imply that SEZpolicy has worked and has induced FDI in the state. Alternatively, to see the robustness of the results, we also use number of Operational SEZs in the state and hypothesize that a state having more number of operational SEZ would be able to attract more FDI.

With respect to other variables, LPGSDP is the log of Per-capita GSDP (at constant Prices), which is used as a measure of size of the market. Higher the GSDP per capita, higher is the market potential. As SEZs are established primarily to attract investment and are export oriented, the size of the domestic market may not be very relevant. However, as we are looking factor influencing total FDI in a state, the market size captured by GSDP per capita becomes relevant. We thus include this variable in the model.

For FDI (be it export-oriented or for domestic market), nearness to Port is very important, as goods can be imported and exported freely. We have included this variable nearness to port (NEARPORT) as a dummy, which takes the value one if the state has a seaport and zero otherwise. As a measure of labour availability we have used level of Urbanisation as indicator. A state having higher urbanisation per unit area (URBANDENSITY) in turn means that it would have more skilled people available. We have proxied infrastructure with two variables - electricity availability per GSDP (PELEC) and highway density (HDENSITY).

\subsection{Sources of Data}

The required data set has been compiled from different sources apart from Indiastat which collates the data published in different secondary sources. The dependent variable in our study is the FDI inflow in million US dollars (USD). The source of FDI inflow data is the Reserve Bank of India (RBI), which publish the data based on their regional offices rather than for the individual state. For example, Maharashtra RBI office consists of FDI data from Maharashtra, Daman and Diu (DD), and Dadar and Nagar Haveli (DNH). Thus, the restriction in the data availability forced us to group the states into 16 groups based on RBI classification. The following groups of states were considered for analysis: (1) Maharashtra, DD, DNH; (2) Delhi; (3) Karnataka; (4) Gujarat; (5) TN, Pondicherry; (6) AP; (7) WB, Sikkim, Andaman and Nicobar Islands (AN Islands); (8) Haryana, Chandigarh, Punjab, Himachal Pradesh (HP); (9) Goa; (10) MP, Chhattisgarh; (11) Rajasthan; (12) Kerala, Lakshadweep; (13) Odisha; (14) Uttar Pradesh (UP), Uttaranchal; (15) Assam, Arunachal Pradesh, Manipur, Mizoram, Nagaland, Tripura, Meghalaya; (16) Bihar, Jharkhand. As Telangana state was formed in 2014, for the purpose of this study, it is clubbed together with AP. The variable as used in the estimation is in log form. Since FDI to several of the states may come intermittently, this implies they may not receive FDI for certain years. In order to not to exclude these observations, a value of 1 is added to FDI value for all the observations and then log is taken.

Market size data as measured by the PCGSDP in constant prices is compiled 
from the Planning Commission website. The data for all the explanatory variables has been regrouped under the same state groups as that of FDI. The data on Electricity Capacity is compiled from CMIE website, Energy statistics of India and Indiastat. The data on highway length has been compiled by the Indiastat from Ministry of Road Transport and Highways and Lok Sabha starred questions. The population data and the urbanisation for the interim period i.e. between 2002 to 2010 and after 2012 are based on projections based on population growth rate and the growth in urbanisation. The states having seaports are identified from the data given in Centre for Coastal Zone Management. The number of Operational SEZ is collected from www.sezindia.nic.in. The data on SEZpolicy is taken from www.sezindia.nic.in. The variables used in the model with their expected signs and source are described in Table 1.

The study uses panel data technique for 16 major states for the period 2001 to 2014 to estimate the model to avoid the potential biasedness that may arise due to state-level heterogeneity, which may not be well captured using cross-section or time-series data.

\section{Descriptive Statistics}

Table 2 gives the state-wise FDI inflows during 2001 to 2014. As can be seen, five states, namely Maharashtra, Delhi, TN, Karnataka, Gujarat and AP have re-

Table 1. Variables description and expected sign.

\begin{tabular}{|c|c|c|c|}
\hline Variables & Description & $\begin{array}{l}\text { Expected } \\
\text { sign }\end{array}$ & Data Source \\
\hline \multicolumn{4}{|c|}{ Dependent Variables } \\
\hline LFDI & $\begin{array}{l}\text { Logarithm of Foreign Direct Investment in USD } \\
\text { million }\end{array}$ & & $\begin{array}{l}\text { Indiastat (originally taken from Lok Sabha Starred } \\
\text { Question\# and Ministry of Commerce and Industry and } \\
\text { RBI) }\end{array}$ \\
\hline \multicolumn{4}{|c|}{ Independent Variables } \\
\hline LPGSDP & $\begin{array}{l}\text { Logarithm of Per capita GSDP in USD (GSDP in } \\
\text { USD million/population in million) }\end{array}$ & + & Planning Commission \\
\hline PELEC & Installed Electricity capacity (MW) per GSDP & + & CMIE website, Energy statistics of India, indiastat \\
\hline HDENSITY & $\begin{array}{l}\text { Highway Density (Length of national highways in } \\
\mathrm{km} / \text { Area) }\end{array}$ & - & $\begin{array}{l}\text { Indiastat (originally data has been taken from Ministry } \\
\text { of Road Transport and Highways and Rajya Sabha and } \\
\text { Lok Sabha questions\$) }\end{array}$ \\
\hline URBANDENSITY & $\begin{array}{l}\text { Urban Density [=(Urban people/Total populations) } \\
\times 100 / \text { Area }]\end{array}$ & + & Census 2001 and 2011 \\
\hline NEARPORT & $\begin{array}{l}\text { Dummy variable with value ' } 1 \text { ' for coastal States } \\
\text { and ' } 0 \text { ' otherwise. }\end{array}$ & + & $\begin{array}{l}\text { Centre for Coastal Zone Management and Coastal } \\
\text { Shelter Belt }\end{array}$ \\
\hline SEZpolicy & $\begin{array}{l}\text { Dummy variable with value ' } 1 \text { ' when state } \\
\text { formulates SEZ policy and ' } 0 \text { ' otherwise. }\end{array}$ & + & $\underline{\text { www.sezindia.nic.in }}$ \\
\hline OPSEZ & Number of Operational SEZs & + & $\underline{\text { www.sezindia.nic.in }}$ \\
\hline
\end{tabular}

Source: Authors' own description. Notes: \#-Lok Sabha Starred Question No. 589, dated 02.05.2003, Unstarred Question No. 1038, dated on 28.11.2006; \$— Lok Sabha Unstarred Question No. 793, dated on 19.03.2012, Rajya Sabha Unstarred Question No. 1836, dated on 28.08.2012, Lok Sabha Starred Question No. 56, dated on 23.07.2015 and Lok Sabha Starred Question No. 178, dated on 10.12.2015. 
Table 2. State wise FDI inflows during 2001 to 2014.

\begin{tabular}{cccc}
\hline States & $\begin{array}{c}\text { Average FDI Inflow } \\
\text { (USD million) }\end{array}$ & \% of FDI & $\begin{array}{c}\text { Total FDI Inflow } \\
\text { (USD million) }\end{array}$ \\
\hline Maharashtra (DNH, DD) & 4854 & 40.60 & 67,954 \\
Delhi & 2801 & 23.43 & 39,215 \\
TN (Pondicherry) & 1128 & 9.44 & 15,792 \\
Karnataka & 1072 & 8.97 & 15,014 \\
Gujarat & 829 & 6.94 & 11,607 \\
AP & 634 & 5.31 & 8881 \\
WB (AN Islands, Sikkim) & 207 & 1.73 & 2901 \\
Rajasthan & 89 & 0.74 & 1241 \\
MP (Chhattisgarh) & 81 & 0.67 & 1130 \\
Kerala (Lakshadweep) & 77 & 0.64 & 1074 \\
Haryana (Chandigarh, Punjab, HP) & 76 & 0.64 & 1063 \\
Goa & 49 & 0.41 & 684 \\
UP (Uttaranchal) & 31 & 0.26 & 434 \\
Odisha & 18 & 0.15 & 250 \\
North Eastern states & 5 & 0.04 & 73 \\
Bihar (Jharkhand) & 4 & 0.03 & 55 \\
\hline
\end{tabular}

Source: Compiled from FDI inflow data from indiastat.

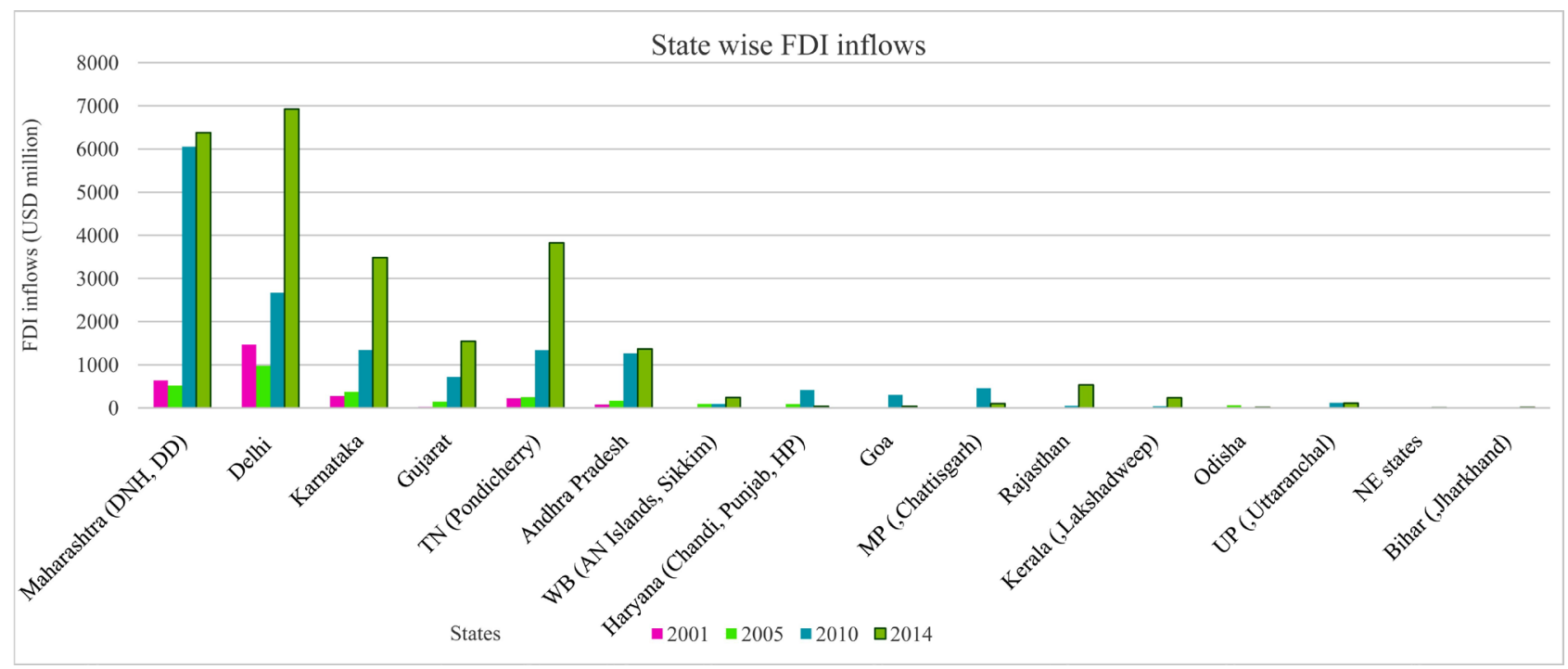

Data Source: Compiled from indiastat; Notes: Same as Figure 1.

Figure 2. FDI Inflows (USD million) in 2001, 2005, 2010 and 2014 in India.

ceived $93 \%$ of FDI. Incidentally, these States are more reform-oriented in comparison to other less reform oriented states like Bihar, UP, Haryana, Kerala, Odisha, MP, Punjab, Rajasthan and WB ([25] [36]).

The FDI flows to different states over different time period is given in Figure 2. As is clear from the figure initially the FDI inflows were low between 2001- 
2005 for all the states after which some of the states like Maharashtra, DD, DNH, Delhi, Karnataka, Gujarat, TN and Pondicherry have experienced increased inflows during 2010-2014. However, Odisha, UP, Uttaranchal, North-Eastern states, Bihar and Jharkhand have attracted very meagre FDI inflow since 2001.

Regarding SEZ policy formulation, Table 3 gives the year when different states formulated the policy. Column 3 of the table gives whether these states have a separate SEZ Act or not. It is interesting to note that states like Maharashtra, Jharkhand, Kerala, Karnataka and Chhattisgarh, though have active SEZ policy, they have not passed any specific Act pertaining to SEZ. Interestingly, despite having SEZ policy and passing of an Act nearly 10 years ago, Goa still does not have even a single SEZ.

Figure 3 gives the trend of Operational SEZ in India from 2001 to 2014. As can be seen from the figure, the rate of increase of the Operational SEZ was higher in the initial years of SEZ Act (i.e., from 2005 to 2010) and it has slowed down especially after 2010. Figure 4, which gives a scatter plot between number of operational SEZ and FDI, indicates that FDI inflow rises as the number of Operational SEZ increases. However, the relation is not linear.

The descriptive statistics of all variables used in the model are given in Table 4. The statistics show that Maharashtra, Delhi, Karnataka, Gujarat and TN have above average FDI inflow (column 1) whereas the states like AP, WB, Haryana, Goa, MP, Rajasthan, Kerala, Odisha, UP, North Eastern states and Bihar have below average FDI inflow. In case of Per-capita GSDP (column 2), Maharashtra, Delhi, Gujarat, TN, Haryana, Goa and Kerala have above average Per-capita GSDP but Karnataka, AP, WB, MP, Rajasthan, Odisha, UP, North Eastern states and Bihar have below average Per-capita GSDP. Likewise, in case of Operational

Table 3. State-wise details of SEZ policy passing year and SEZ Act enactment year.

\begin{tabular}{ccc}
\hline States & Year of passing of SEZ policy & Year of enactment of SEZ Act \\
\hline Maharashtra & 2001 & No \\
WB & 2001 & 2003 \\
MP & 2001 & 2003 \\
TN & 2003 & 2005 \\
Jharkhand & 2003 & No \\
Punjab & 2005 & 2009 \\
Chandigarh & 2005 & No \\
Haryana & 2006 & 2005 \\
Goa & 2006 & No \\
UP & 2007 & 2002 \\
Kerala & 2008 & No \\
Karnataka & 2009 & No \\
Chhattisgarh & 2011 & No
\end{tabular}

Source: Compiled from http://www.sezindia.nic.in/ and http://www.investindia.gov.in/state-policies/; Note: Here 'No' means that the state has not enacted a separate SEZ Act yet. 


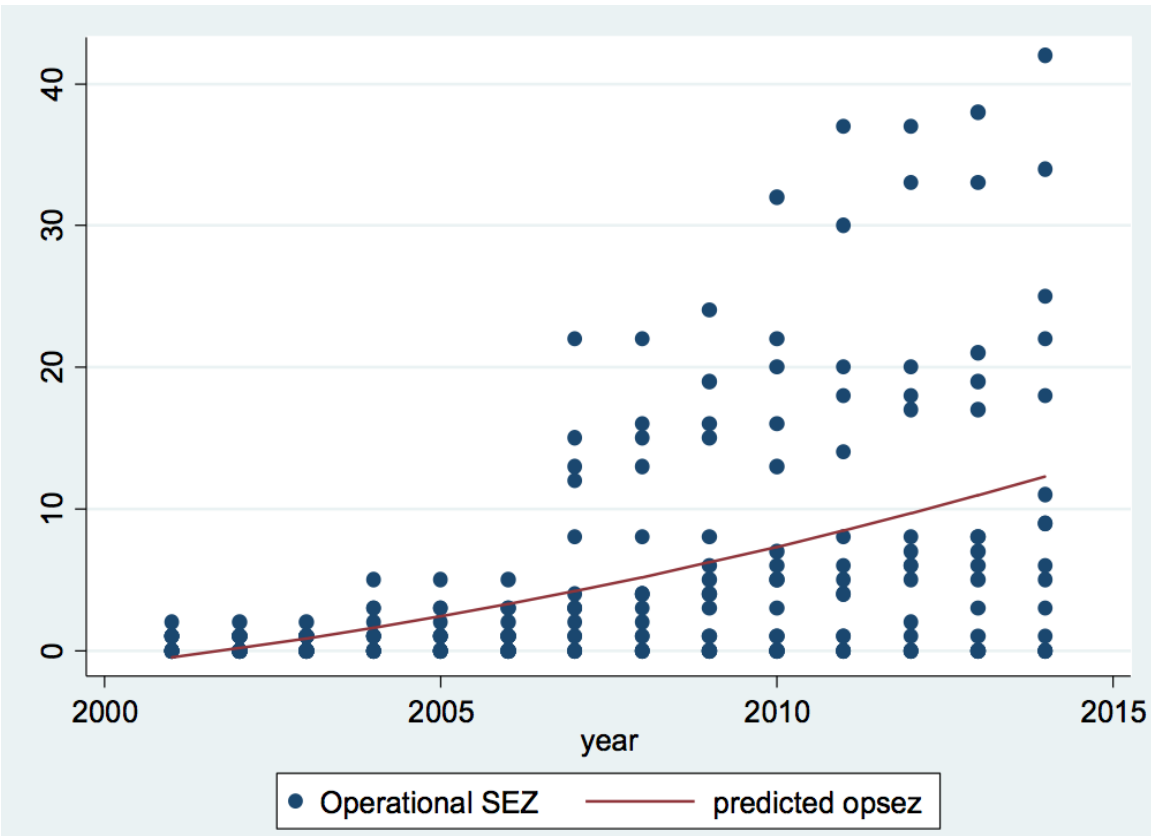

Data Source: Compiled from Indiastat.

Figure 3. Trend of Operational SEZ from 2001 to 2014.

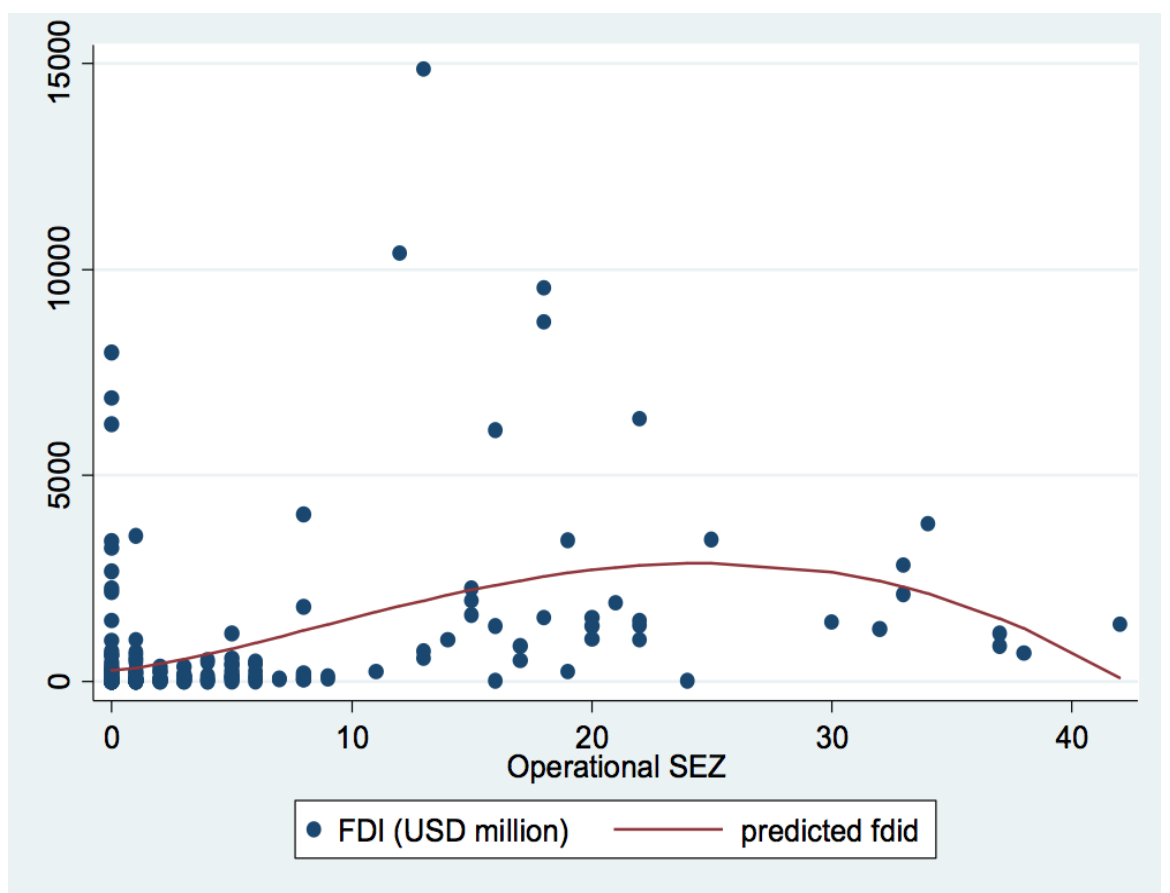

Data Source: Compiled from Indiastat.

Figure 4. Relation between Operational SEZ and FDI inflow.

SEZ (column 7), Maharashtra, Karnataka, Gujarat, TN and AP could establish more than 10 number of Operational SEZs over the period, whereas, MP, Rajasthan, Kerala, Odisha, UP, have less than five Operational SEZs. It can be seen from the Table 4 that among all the states, TN has above average value for all the variables whereas Odisha has below average value for all these variables. 
Table 4. Mean Values of variables over 2001 to 2014.

\begin{tabular}{|c|c|c|c|c|c|c|c|}
\hline State/Region & $\begin{array}{l}\text { FDI (USD } \\
\text { million) } \\
(1)\end{array}$ & $\begin{array}{c}\text { Per capita } \\
\text { GSDP (USD) } \\
(2)\end{array}$ & $\begin{array}{c}\text { Electricity } \\
\text { capacity (MW) } \\
\text { (3) }\end{array}$ & $\begin{array}{c}\text { Highway }(\mathrm{km}) \\
\text { (4) }\end{array}$ & $\begin{array}{c}\text { Urbanisation (\%) } \\
\text { (5) }\end{array}$ & $\begin{array}{l}\text { Nearport } \\
(6)\end{array}$ & $\begin{array}{c}\text { OpSEZ } \\
\text { (in no.)\# } \\
\text { (7) }\end{array}$ \\
\hline Maharashtra, DD, DNH & $4853.9(4590.7)$ & $1149.2(357.8)$ & $21,817.7(7746.6)$ & $4608.6(837.2)$ & $44.3(1.2)$ & 1 & 22 \\
\hline Delhi & $2801.5(2530.6)$ & $1897.7(601.2)$ & $4626.8(2081.8)$ & $87.1(18.8)$ & $96.0(1.9)$ & 0 & 0 \\
\hline Karnataka & $1072.5(997.9)$ & $803.4(229.7)$ & $9649.5(3329.6)$ & $4281.1(687.04)$ & $37.2(2.1)$ & 1 & 25 \\
\hline Gujarat & $829.1(1077.6)$ & $1064.5(351.4)$ & $15,239.7(7541.7)$ & $3373.9(731.3)$ & $40.9(2.4)$ & 1 & 18 \\
\hline TN, Pondicherry & $1128.0(1133.4)$ & $979.1(320.6)$ & $14,601.9(4511.1)$ & $5156.2(1221.7)$ & $47.3(1.9)$ & 1 & 34 \\
\hline AP, Telangana & $634.3(545.3)$ & $795.1(243.2)$ & $12,111.5(3725.6)$ & $4992.3(878.9)$ & $31.6(2.9)$ & 1 & 42 \\
\hline WB, Sikkim, AN Islands & $207.2(192.5)$ & $626.2(131.4)$ & $7759.6(1347.8)$ & $2874.0(606.5)$ & $30.6(1.8)$ & 1 & 6 \\
\hline $\begin{array}{c}\text { Haryana, HP, } \\
\text { Chandigarh, Punjab }\end{array}$ & $75.9(111.3)$ & $1087.8(286.5)$ & $14,553.1(4273.2)$ & $4934.3(875.6)$ & $33.0(1.9)$ & 0 & 9 \\
\hline Goa & $48.9(75.8)$ & $2506.1(932.8)$ & $380.3(49.2)$ & $269(0)$ & $58.7(6.04)$ & 1 & 0 \\
\hline MP, Chhattisgarh & $80.7(124.9)$ & $480.0(123.9)$ & $12,761.1(6505.3)$ & $7875.4(1315.1)$ & $25.9(0.7)$ & 0 & 3 \\
\hline Rajasthan & $88.7(160.1)$ & $549.6(136.5)$ & $7902.4(3739.6)$ & $6088.2(1161.2)$ & $24.4(0.6)$ & 0 & 5 \\
\hline Kerala, Lakshadweep & $76.6(128.1)$ & $1017.6(311.9)$ & $3474.5(433.3)$ & $1490.8(58.3)$ & $46.1(15.3)$ & 1 & 11 \\
\hline Odisha & $17.9(21.1)$ & $522.9(154.4)$ & $5133.9(1736.2)$ & $4079.1(709.2)$ & $16.1(0.7)$ & 1 & 1 \\
\hline UP, Uttaranchal & $30.9(50.03)$ & $395.9(94.7)$ & $12,766.9(2883.9)$ & $8472.2(1872.8)$ & $22.1(0.7)$ & 0 & 9 \\
\hline North Eastern States & $5.2(10.7)$ & $515.8(113.1)$ & $2308.7(319.7)$ & $7565.4(1163.6)$ & $17.6(1.3)$ & 0 & 0 \\
\hline Bihar, Jharkhand & $3.9(6.8)$ & $291.3(78.3)$ & $4391.1(525.9)$ & $5989.7(1054.8)$ & $14.0(0.4)$ & 0 & 0 \\
\hline Overall Mean for all states & 747.2 & 917.6 & 9342.4 & 4508.6 & 36.6 & & 185 \\
\hline
\end{tabular}

Source: Own computation; Notes: D \& D-Daman and Diu; D \& N Haveli-Dadra and Nagar Haveli; TN-Tamil Nadu; A \& N Island-Andaman and Nicobar Island; WB-West Bengal; HP-Himachal Pradesh; MP—Madhya Pradesh; UP -Uttar Pradesh and NE states—North Eastern states which include Assam, Tripura, Meghalaya, Mizoram, Manipur, Arunachal Pradesh and Nagaland. The values in parenthesis are standard deviation; \#-operational SEZs are total number of Operational SEZs during 2014.

Table 5 compares different variables prior to and after formulating the SEZ policy. As mentioned, SEZpolicy is a dummy which takes the value "1", when the state formulated the SEZ policy and zero otherwise. For example, Maharashtra has formulated SEZ policy in 2001 (Table 3), thus the value of SEZpolicy variable for Maharashtra is "1" from 2001 to 2014. Likewise, values are given for all states. Some states like Bihar and North Eastern states do not have any SEZ policy and have "0" value throughout the period. Also, the states like Odisha and Rajasthan have formulated SEZ policy in 2015 and as the study period is only upto 2014, the value of SEZpolicy variable for these states is taken as ' 0 '. The $t$ test has been carried out to find whether there is any significant change in these variables after SEZ policy. It is found from Table 5 that all variables except Urbanisation, are not only higher but also statistically significant. The comparison yields that formulation of SEZ policy has resulted in increased FDI inflow, increased per capita income, more electricity generation, more high way density and more number of operational SEZ in a particular state. 
Table 5. Impact of SEZ policy—comparison before and after passing of this policy.

\begin{tabular}{cccc}
\hline Variable & All $(\mathrm{N}=\mathbf{2 2 4})$ & $\begin{array}{c}\text { Before SEZ Policy } \\
(\mathrm{N}=106)\end{array}$ & $\begin{array}{c}\text { After SEZ Policy } \\
(\mathbf{N}=118)\end{array}$ \\
\hline LFDI & $4.14(2.64)$ & $3.81(2.62)$ & $4.44^{\star}(2.63)$ \\
LPCGSDP & $6.62(0.63)$ & $6.49(0.64)$ & $6.73^{*}(0.59)$ \\
ELEC GEN (MW) & $8.79(0.066)$ & $8.67(0.082)$ & $8.91^{*}(0.102)$ \\
HDENSITY & $0.03(0.02)$ & $0.029(0.0017)$ & $0.033^{*}(0.0014)$ \\
URBANISATION (\%) & $36.63(20.09)$ & $37.62(24.91)$ & $35.74(14.52)$ \\
OPSEZ (No.) & $5.16(8.55)$ & $2.04(3.99)$ & $7.96^{*}(10.41)$ \\
\hline
\end{tabular}

Source: Own Computation; Note: Figure in parenthesis are standard Deviation; ${ }^{\star}$ denotes the variable is statistically significant at $10 \%$ level.

Table 6. VIF computation.

\begin{tabular}{ccc}
\hline Variable & VIF & $1 /$ VIF \\
\hline LPCGSDP & 2.41 & 0.41 \\
PELEC & 1.40 & 0.72 \\
HDENSITY & 2.09 & 0.48 \\
URBANDENSITY & 2.51 & 0.39 \\
NEARPORT & 1.53 & 0.65 \\
SEZPOLICY & 1.56 & 0.64 \\
\hline
\end{tabular}

Source: Own computation.

\section{Results}

Before carrying out analysis, we tested for multicollinearity (correlation matrix is given in the appendix, Table A2). As can be seen from the table, States with sea port have not only had higher urban density, higher per-capita GSDP, but also higher highway density. The number of operational SEZs is found to be positively correlated to the per-capita income, availability of electricity, urbanisation, SEZ policy and nearness to the port but negatively correlated to highway density. This is not surprising as given the purpose of setting up of SEZs, which is meant for exports, they not only require larger parcel of land at a particular location, but also would be away from urban centres but nearer to a port. The severity of the multicollinearity problem is checked by Variance Inflation Factor (VIF) (Table 6). As the VIF values are less than 10 and tolerance value (1/VIF) is greater than 0.1, this implies multicollinearity though exists, it is not a serious problem.

The Equation (2) has been estimated in three different ways ${ }^{5}-1$ ) pooled model (keeping $\alpha$ constant i.e. ignoring the state specific or temporal effects); 2) fixed effects; and 3) random effects. As the states are heterogeneous, random effects and fixed effects models control for the state specific effects, and the suitability of these models is tested using the Hausman specification test. We tested for the

${ }^{5}$ All the analysis is carried out in STATA 13.1. 
Table 7. Does SEZ induce FDI inflow? - Panel data Regression results.

\begin{tabular}{|c|c|c|c|c|c|}
\hline Variables & $\begin{array}{l}\text { OLS } \\
(1)\end{array}$ & $\begin{array}{c}\text { Fixed Effect } \\
\text { (2) }\end{array}$ & $\begin{array}{c}\text { Random Effect } \\
\text { (3) }\end{array}$ & $\begin{array}{l}\text { Regression with } \\
\text { panel-corrected } \\
\text { standard errors }(4)\end{array}$ & $\begin{array}{c}\text { Regression with } \\
\text { panel-corrected standard } \\
\text { errors (SEZPOLICY replaced } \\
\text { with OPSEZ variable) (5) }\end{array}$ \\
\hline \multicolumn{6}{|c|}{ (Dependent Variable = LFDI) } \\
\hline LPCGSDP & $2.48^{\star * \star}(0.27)$ & $1.95^{\star * \star}(0.29)$ & $2.15^{\star * \star}(0.28)$ & $2.47^{\star \star \star}(0.46)$ & $2.11^{\star \star \star}(0.42)$ \\
\hline ELEC & $4.69^{* *}(1.82)$ & $3.05(1.83)$ & $3.28(1.75)$ & $3.70(2.57)$ & $0.78(2.1)$ \\
\hline HWDNSTY & $-89.99^{* * *}(9.8)$ & $-97.27^{* * *}(9.38)$ & $-96.08^{\star * \star}(9.27)$ & $-88.49^{\star * \star}(16.1)$ & $-72.18^{\star * *}(14.95)$ \\
\hline URBANDN & $83.40^{* * *}(9.63)$ & $96.02^{\star \star \star}(10.13)$ & $91.99^{\star * \star}(10.11)$ & $78.84^{\star * \star}(18.14)$ & $70.98^{\star \star \star}(15.7)$ \\
\hline NEARPRT & $1.56^{* * *}(0.3)$ & $1.91^{\star * \star}(0.26)$ & $1.79^{\star * *}(0.26)$ & $1.53^{\star \star}(0.46)$ & $1.20^{\star \star \star}(0.43)$ \\
\hline SEZPOLICY & $1.18^{\star * \star}(0.24)$ & $0.85^{\star \star}(0.26)$ & $0.97^{\star \star *}(0.26)$ & $1.17^{\star \star}(0.39)$ & \\
\hline OpSEZ & & & & & $0.09^{* * *}(0.02)$ \\
\hline Constant & $-12.33^{* * *}(1.59)$ & $-8.35^{\star \star \star}(1.77)$ & $-9.68^{\star * \star}(1.69)$ & $-11.87^{\star \star \star}(2.95)$ & $-8.98^{\star \star}(2.71)$ \\
\hline Observations & 224 & 224 & 224 & 224 & 224 \\
\hline$R$ squared & 0.62 & 0.66 & 0.66 & 0.71 & 0.81 \\
\hline F test & 59.25 & 65.77 & - & - & - \\
\hline Wald Chi 2 & - & - & 396.36 & 104.80 & 152.01 \\
\hline Hausman test & & \multicolumn{2}{|c|}{$\operatorname{chi} 2(6)=10.47$} & & \\
\hline $\begin{array}{l}\text { Breusch-Pagan } \\
\text { /Cook-Weisberg test } \\
\text { for heteroskedasticity }\end{array}$ & & \multicolumn{2}{|c|}{$\operatorname{chi} 2(1)=0.01$} & & \\
\hline $\begin{array}{l}\text { Wooldridge test for } \\
\text { autocorrelation }\end{array}$ & & \multicolumn{2}{|c|}{$F(1,13)=17.586$} & & \\
\hline
\end{tabular}

Source: Authors' own computations using OLS and panel data techniques. For the sources of data, kindly refer Table 1. Notes: ${ }^{* *}$, ${ }^{* *}$ and ${ }^{*}$ indicates significance at minimum $1 \%, 5 \%$ and $10 \%$ respectively. Figures in parenthesis are standard errors.

presence of time effects in the fixed effects model and found them to be not significant and hence the results are not reported here. The estimated results are given in Table 7. Column 2 presents the results where the state-level differences are not considered. Though, we do not see any evidence of heteroscedasticity from the Bruesch-Pagan/Cook-Weisberg test, we report robust standard errors after correcting for heteroskedasticity. Columns 3 and 4 give the results for fixed effects and random effects estimation. The F statistic (5.76 with prob. $>0$ ) indicates that the state-level differences are important.

To check the suitability of fixed effects vis-à-vis the random effects, a Hausman test is carried out. As the test statistic (10.47) is lesser than the critical value, the null of Random effect being more efficient is accepted. We also carry out and additional test, Breush Pagan Lagrangian Multiplier test for random effect. The test statistics of 59.84 (prob. $=0.00$ ) validates that random effect model is efficient in the present case. The Wooldridge test with value 17.58 (prob. $=0.00$ ) indicates the presence of autocorrelation in the sample. Column 5 reports the results of the model corrected for panel specific autocorrelation. Since model given in Column 5 is our preferred model, we discuss these results only. 
The results validate that SEZ policy has a direct influence on the FDI inflows in a state. The results indicate that a state which has formulated SEZ policy will be able to attract additional 3.21 million USD $\left(=\exp \left(\beta_{6}\right)\right)$ FDI; vis-à-vis a state, which has not formulated the policy. Besides the policy formulation, other factors influencing FDI inflows are the market size and Urbanisation. A state having a seaport is also able to attract more FDI. Surprisingly, electricity generation in a state has no bearing on FDI inflow. One possibility could be that it is not the electricity generation as such, rather it is electricity availability that would influence FDI inflow. We did not have data to account for electricity availability; as a result we could include only energy generation variable only. Surprisingly, we find that highway density has a negative influence on FDI inflow. One probable reason is that extent of road infrastructure is not merely reflected by highways, even a simple tar road may add up to the infrastructure. For lack of data on all kinds of roads in a particular state for all the years, we could not include the variable.

To check the robustness of the results, we use number of operational SEZs instead of SEZ policy. The results are reported in column 6 of the table. All the variables retain same sign and significance. The key variable, i.e., no. of operational SEZ is not only positive but also statistically significant. This suggests that a state having more number of operational SEZ is able to attract more FDI. As a further robustness test (results not reported), we also looked into the effect of operational SEZ after removing all the variables except market size. Our key variable retains the same sign and significance. Thus to conclude, having an SEZ policy or more number of operational SEZ has resulted in higher FDI in a particular state, even when we account for other location specific variables like market size, nearness to coast or highway density.

\section{Conclusions}

The present study aimed to understand whether establishment of Special Economic Zones (SEZs) have succeeded in attracting more FDI in state. Towards this end, a panel data analysis of 16 states for the period 2001 to 2014 has been carried out to establish the relation between FDI inflows and SEZ policy after accounting for other state-specific variables (such as market size, infrastructure, location, and labour availability) having impact on FDI inflow. The results obtained were in tandem with the literature and showed that FDI inflows are significant in the states with higher Per-capita income (market size), Urbanisation and the Coastal infrastructure (nearness to the ports). The states which attracted more FDI-Maharashtra, Karnataka, Gujarat, TN and AP are all coastal states. However, the North Eastern states, Bihar and Jharkhand have a minimum number of SEZs and also very low FDI. It is also seen that the operational SEZs are mainly concentrated in those states with higher FDI, and thus may further exacerbate regional inequality.

The results do indicate a positive and significant relationship between FDI inflow and the formulation of SEZ policy. The results are robust to when we in- 
clude the number of operational SEZs instead of SEZ policy as a variable explaining FDI in these states. The results thus indicate positive role of SEZ policy and operational SEZ for attracting FDI in a state. The results are in line with the findings of Aggarwal [22], who showed that the EPZs generated significant FDI inflows and Wang [11] who noticed an increase in foreign owned capital due to SEZs.

The earlier 18 SEZs which are established before enactment of SEZ Act 2005, are situated in following states, viz. Gujarat (3), Maharashtra (1), UP (2), TN (5), Kerala (1), WB (3), AP (1), Rajasthan (1), MP $(1)^{6}$. The irony is that not all of these states have been able to attract FDI inflow. Among the above mentioned states, only Gujarat, Maharashtra and TN are successful in getting FDI inflow, thus corroborating the view of Kathuria and Rajesh Raj [36] FDI flows are different across the states in India.

From policy perspective, if the objective of setting SEZ is to bring in more equitable growth among the states, this does not seem to concur with the results. FDI is still concentrated in those states, which has some locational advantages. FDI inflows have potential to develop the poorer states but on the contrary these states cannot attract FDI as the investors always look for states which offer them infrastructural, market advantages along with a risk free environment.

In terms of contribution, this study has attempted to find the relationship between SEZ and FDI in Indian context. The study has shown that the enactment of SEZ policy as well as operational SEZs in a state has increased FDI inflow. This can be relevant from the policy perspective for the states which want to get benefit from FDI inflow, they will require to enact SEZ policy sooner.

There are some avenues for further research. First of all, whether or not the magnitude of inflows is sufficient enough to offset the losses that the Government is incurring in foregoing the tax revenues, the impact on environment SEZs have etc. is a subject of further analysis.

The present study can be further improved by constructing an infrastructure index. The variables like electricity availability per GSDP and highway density have been used as proxy for infrastructure index. Another area of further research is looking into the nature of SEZ that can attract maximum FDI. In the present study, there was no distinction between whether SEZ is electronics or food processing or biotechnology or textile or mixed, it is possible that more mixed SEZ may attract more FDI.

\section{Acknowledgements}

An earlier version of the paper was presented in at $51^{\text {st }}$ Annual conference held by The Indian Econometric Society (TIES) during $12^{\text {th }}-14^{\text {th }}$ December 2014 at Punjabi University Patiala. We are extremely thankful to conference participants ${ }^{6}$ The location of these SEZs is Kandla SEZ, Surat SEZ, Surat Apparel Park in Gujarat, Santacruz SEZ in Maharashtra, Noida and Moradabad SEZ in UP, Madras SEZ, Mahindra City SEZ (IT), Mahindra City SEZ (Auto Ancillary), Mahindra City SEZ (Textiles) and Nokia SEZ in TN, Cochin SEZ in Kerala, Falta SEZ, Manikanchan SEZ, and Salt Lake Electronic City-WIPRO in WB, Vishakhapatnam SEZ in AP, Jaipur SEZ in Rajasthan and Indore SEZ in MP. 
for the comments. The usual disclaimers apply. We express our sincere gratitude for anonymous reviewer(s) for their comments on the earlier version of this paper.

\section{References}

[1] Gopinath, D. (2009) Contemporary Approaches to Economic Development: The Special Economic Zone Programme. Local Economy, 24, 448-455. https://doi.org/10.1080/02690940903319018

[2] Madani, D. (1995) A Review of the Role and Impact of Export Processing Zones. World Bank, Washington DC.

[3] World Bank (2008) Special Economic Zones: Performance, Lessons Learned, and Implications for Zone Development. World Bank, Washington DC.

[4] Wong, K.Y. and Chu, D.K.Y. (1984) Export Processing Zones and Special Economic Zones as Generators of Economic Development: The Asian Experience. Geografiska Annaler. Series B, Human Geography, 66, 1-16. https://doi.org/10.2307/490524

[5] Johansson, H. and Nilsson, L. (1997) Export Processing Zones as Catalysts. World Development, 25, 2115-2128. https://doi.org/10.1016/S0305-750X(97)00103-4

[6] Palit, A. and Bhattacharjee, S. (2008) Special Economic Zones in India: Myths and Realities. Anthem South Asian Studies, New Delhi.

[7] Special Economic Zones in India (2016) http://www.sezindia.nic.in

[8] Singala, S., Atmavilas, Y. and Singh, E. (2011) Special Economic Zones in India: Policies, Performance and Problems. ASCI Journal of Management, 40, 21-59.

[9] Canfei, H. (2006) Regional Decentralisation and Location of Foreign Direct Investment in China. Post Communist Economies, 18, 33-50. https://doi.org/10.1080/14631370500505131

[10] Ansari, M.S. and Ranga, M. (2010) India's Foreign Direct Investment: Current Status, Issues and Policy Recommendations. UTMS Journal of Economics, 1, 1-16.

[11] Wang, J. (2013) The Economic Impact of Special Economic Zones: Evidence from Chinese Municipalities. Journal of Development Economics, 101, 133-147. https://doi.org/10.1016/j.jdeveco.2012.10.009

[12] Tuan, C. and Ng, L.F.Y. (2002) FDI in China and Regional Development: From Institutional Reform to Agglomeration Economies Perspective. Paper for the First International Conference on Nation States and Economic Policy. Conflict and Cooperation, Tokyo, 30 November-1 December 2002.

[13] Fujita, M. and Hu, D. (2001) Regional Diversity in China 1985-1994: The Effects of Globalization and Economic Liberalization. Annals of Regional Science, 35, 3-37. https://doi.org/10.1007/s001680000020

[14] Cheng, L.K. and Kwan, Y.K. (2000) What Are the Determinants of the Location of Foreign Direct Investment? The Chinese Experience. Journal of International Economics, 51, 379-400. https://doi.org/10.1016/S0022-1996(99)00032-X

[15] Kathuria, V. (2000) Productivity Spillovers from Technology Transfer to Indian Manufacturing Firms. Journal of International Development, 12, 343-369.

[16] Kathuria, V. (2002) Liberalisation, FDI and Productivity Spillovers an Analysis of Indian Manufacturing Firms. Oxford Economic Papers, 54, 688-718. https://doi.org/10.1093/oep/54.4.688

[17] Himachalapathy, R. (2010) A Comparative Analysis of FDI in India and China. Journal of Contemporary Research in Management, 5, 127-158.

[18] Chandran, M. and Balu, A. (2011) Foreign Direct Investment Trends in India. International Journal of Recent Scientific Research, 2, 237-240. 
[19] Saravanan, S. (2014) Foreign Direct Investment in India: A Note. International Journal of Applied Research and Studies, 3, 1-9.

[20] Mukherjee, A. (2011) Regional Inequality in Foreign Direct Investment Flows to India: The Problem and the Prospects. Reserve Bank of India Occasional Papers, 32, 99-127.

[21] Neelakanta, N.T., Gundimeda, H. and Kathuria, V. (2014) Foreign Direct Investment, Pollution and Economic Growth in India: Testing Using ARDL Approach. The Empirical Economics Letters, 13, 317-326.

[22] Aggarwal, A. (2005) The Influence of Labour Markets on FDI: Some Empirical Explorations in Export Oriented and Domestic Market Seeking FDI across Indian States. Paper for the Competitive section of the Global Conference on Business and Economics, London, 25-27 June 2005.

[23] Neelakanta, N.T., Gundimeda, H. and Kathuria, V. (2013) Does Environmental Quality Influence FDI Inflows? A Panel Data Analysis. Review of Market Integration, 5, 303-328. https://doi.org/10.1177/0974929214538362

[24] Siddharthan, N.S. (2006) Regional Differences in FDI Inflows: China-India Comparison, Social Sciences. Working Paper, 438, 1-20.

[25] Bajpai, N. and Sachs, J.D. (2000) Foreign Direct Investment in India: Issues and problems. Development Discussion Paper No. 759. Harvard Institute for International Development, Cambridge.

[26] Aggarwal, A. (2006) Special Economic Zones: Revisiting the Policy Debate. Economic and Political Weekly, 41, 4533-4536.

[27] Makabenta, M.P. (2002) FDI Location and Special Economic Zones in the Philippines. Review of Urban \& Regional Development Studies, 14, 59-77.

https://doi.org/10.1111/1467-940X.00048

[28] Abbas, Q., Akbar, S., Nasir, A.S., Ullah, A.H. and Naseem, M.A. (2011) Impact of Foreign Direct Investment on Gross Domestic Product. Global Journal of Management and Business Research, 11, 1-5.

[29] Szkorupová, Z. (2014) A Casual Relationship between Foreign Direct Investment, Economic Growth and Export for Slovakia. Procedia Economics and Finance, 15, 123-128. https://doi.org/10.1016/S2212-5671(14)00458-4

[30] Kumar, N. (2002) Infrastructure Availability, Foreign Direct Investment Inflows and Their Export Orientation: A Cross Country Exploration. RIS Discussion Paper.

[31] Banga, R. (2003) Impact of Government Policies and Investment Agreements of FDI Inflows. Working paper No. 116. Indian Council for Research on International Economic Relations (ICRIER), New Delhi.

[32] Chatterjee, S., Mishra, P. and Chatterjee, B. (2013) Determinants of Inter-State Variations in FDI Inflows in India. Eurasian Journal of Business and Economics, 6 , 93-120.

[33] Kathuria, V. (2016) What Causes Agglomeration-Policy or Infrastructure?-A Study of Indian Organized Manufacturing Industry. Economic and Political Week$1 y, 51,33-44$.

[34] Sinha, S.S., Kent, D.H. and Shomali, H. (2007) Comparative Analysis of FDI in China and India. Journal of Asia Entrepreneurship and Sustainability, 3, 1-20.

[35] Anh, N.T.N. (2016) Regional Determinants of FDI Location in Vietnam. Journal of Economic Development, 18, 19-37.

[36] Kathuria, V. and Natarajan, R.R. (2013) Is Manufacturing an Engine of Growth of India in the Post-Nineties? Journal of South Asian Development, 8, 385-408. https://doi.org/10.1177/0973174113504849. 


\section{Appendix}

Table A1. Sector-wise SEZ.

\begin{tabular}{|c|c|c|c|c|c|c|}
\hline Sectors & $\begin{array}{c}\text { Formal Approvals } \\
\text { (No.) }\end{array}$ & $\begin{array}{c}\text { Formal } \\
\text { Approval (\%) }\end{array}$ & $\begin{array}{c}\text { In-Principal } \\
\text { Approvals (No.) }\end{array}$ & $\begin{array}{c}\text { In-Principal } \\
\text { Approvals (\%) }\end{array}$ & $\begin{array}{l}\text { Notified } \\
\text { (No.) }\end{array}$ & Notified (\%) \\
\hline Agro & 4 & 1 & 2 & 6 & 4 & 1 \\
\hline Biotechnology & 23 & 6 & 0 & 0 & 16 & 5 \\
\hline Engineering & 15 & 4 & 1 & 3 & 15 & 5 \\
\hline Footwear/Leather & 6 & 1 & 0 & 0 & 5 & 2 \\
\hline Food Processing & 4 & 1 & 0 & 0 & 3 & 1 \\
\hline FTWZ & 10 & 2 & 4 & 13 & 7 & 2 \\
\hline $\begin{array}{c}\text { IT/ITES/Electronic } \\
\text { Hardware/Semiconductor/Services }\end{array}$ & 262 & 63 & 0 & 0 & 204 & 62 \\
\hline Multi-product & 19 & 5 & 11 & 34 & 17 & 5 \\
\hline Multi-Services & 7 & 2 & 1 & 3 & 7 & 2 \\
\hline Non-Conventional Energy & 2 & 0 & 0 & 0 & 2 & 1 \\
\hline Petrochemicals and petro./oil and gas & 2 & 0 & 1 & 3 & 0 & 0 \\
\hline Pharmaceuticals/chemicals & 16 & 4 & 2 & 6 & 16 & 5 \\
\hline Port-based multi-product & 5 & 1 & 1 & 3 & 3 & 1 \\
\hline Others & 42 & 10 & 9 & 28 & 31 & 9 \\
\hline Total & 417 & 100 & 32 & 100 & 330 & 100 \\
\hline
\end{tabular}

Source: Own compilation from http://www.sezindia.nic.in/.

Table A2. Spearman rank correlation matrix.

\begin{tabular}{|c|c|c|c|c|c|c|c|}
\hline & LPCGSDP (1) & ELEC (2) & HWDNSTY (3) & URBANDN (4) & SEZPLCY (5) & NEARPRT (6) & OPSEZ (7) \\
\hline LPCGSDP & 1.00 & & & & & & \\
\hline ELEC & $-0.24^{\star}$ & 1.00 & & & & & \\
\hline HWDNSTY & $0.40^{*}$ & $-0.44^{*}$ & 1.00 & & & & \\
\hline URBANDN & $0.73^{*}$ & $-0.21^{\star}$ & $0.60^{*}$ & 1.00 & & & \\
\hline NEARPRT & $0.36^{*}$ & 0.04 & -0.09 & $0.49^{*}$ & 1.00 & & \\
\hline SEZPLCY & $0.21^{*}$ & $-0.41^{\star}$ & $0.22^{*}$ & 0.04 & 0.07 & 1.00 & \\
\hline OPSEZ & $0.32^{*}$ & 0.11 & $-0.20^{*}$ & 0.09 & $0.39^{*}$ & $0.35^{*}$ & 1.00 \\
\hline
\end{tabular}

Source: Own computation; Note. ${ }^{*}$ shows significance of correlation coefficient at minimum $5 \%$ level. 
Submit or recommend next manuscript to SCIRP and we will provide best service for you:

Accepting pre-submission inquiries through Email, Facebook, LinkedIn, Twitter, etc. A wide selection of journals (inclusive of 9 subjects, more than 200 journals)

Providing 24-hour high-quality service

User-friendly online submission system

Fair and swift peer-review system

Efficient typesetting and proofreading procedure

Display of the result of downloads and visits, as well as the number of cited articles Maximum dissemination of your research work

Submit your manuscript at: http://papersubmission.scirp.org/

Or contact tel@scirp.org 